\title{
KILKA UWAG \\ O INSTYTUCJACH RYNKU PRACY
}

\section{WPROWADZENIE}

Spośród wielu zmian, jakie dokonały się w Polsce w związku z transformacją ustrojową w roku 1989, szczególną rolę odegrało wyłonienie się poszczególnych instytucji rynku pracy. Ów rynek stanowił ogromną liczbę wyzwań, które należało podjąć przy jednoczesnym pojawieniu się problemów, które należało rozwiązać. Polityka zatrudnienia była raczkującą dziedziną prawną, stanowiącą mały podzbiór prawa pracy. Niezwykła dynamika przemian społecznych miała wówczas istotny wpływ na kształtowanie się procesów prawnych w odradzającej się Polsce. Niezliczona gama ówczesnych problemów znajduje swoje odzwierciedlenie także i dziś. Wśród nich należy wskazać:

- likwidację poszczególnych zakładów lub stanowisk pracy,

- trendy płynące z polityki zatrudnienia krajów Europy Zachodniej,

- zbyt wygórowane wymagania organizacyjne i przede wszystkim płacowe pracowników,

- brak szeroko pojętej mobilności pracowników,

- brak umiejętności asymilacji pracowników w nowym miejscu pracy,

- niechęć do przekwalifikowania się,

- brak zdobywania praktyki zawodowej w trakcie kształcenia zawodowego lub uniwersyteckiego.

Ten szereg problemów wskazuje, iż rynek pracy stoi przed nie lada problemem sprostania mnogości stawianych mu wymagań. Administracja pracy, rozumiana jako zbiór osób odpowiedzialnych za wdrażanie instrumentów polityki państwa, służących przeciwdziałaniu pogłębiania się kryzysu dostrzegalnego w polskiej polityce

* Doktorant, Katedra Postępowania Administracyjnego Porównawczego, Uniwersytet Łódzki, ekspert Ministerstwa Administracji i Cyfryzacji. 
zatrudnienia, będzie musiała odpowiednio szybko i skutecznie reagować na powstające problemy.

Aby móc owocnie wskazać szereg instrumentów, które gwarantują stawienie czoła wskazanym wcześniej problemom, należy podjąć próbę właściwego zdefiniowania pojęcia instrumentów rynku pracy. Poprzez instytucje rynku pracy należy rozumieć ogół prawnych narzędzi w aktualnie prowadzonej przez organy państwa polityce zatrudnienia, które powiązane ze sobą w sposób funkcjonalny, zapewniają niwelowanie problemów związanych z szeroko rozumianym zjawiskiem bezrobocia.

Istnieje niewątpliwa konieczność ze strony państwa właściwego kształtowania polityki rynku pracy. Chodzi tutaj o przejaw znanego w prawie powszechnie obowiązującym zjawiska istnienia tak zwanej administracji świadczącej, której wszelkie działania prowadzą do zaspokojenia podstawowych potrzeb ludności. Instrumenty rynku pracy są jej wyraźnym przykładem. Muszą one poprzez swoją fachowość, funkcjonalność i skuteczność właściwie odpowiadać na wymagania stawiane przez nowe trendy na polskim rynku pracy.

Niniejsze opracowanie nie jest zbiorem podręcznikowych myśli akademickich. Zamiarem autora jest poradnikowe ujęcie problemów związanych z istnieniem i funkcjonowaniem podstawowych instrumentów rynku pracy.

Prawna regulacja instytucji rynku pracy znajduje się w ustawie z dnia 20 kwietnia 2004 roku o promocji zatrudnienia i instytucjach rynku pracy ${ }^{1}$. Artykuł 6 wskazanej ustawy wymienia jako instytucje rynku pracy następujące podmioty:

- publiczne służby zatrudnienia,

- Ochotnicze Hufce Pracy,

- agencje zatrudnienia,

- instytucje szkoleniowe,

- instytucje dialogu społecznego,

- instytucje partnerstwa lokalnego.

Podstawowym kryterium, pozwalającym zakwalifikować konkretne podmioty jako instytucje rynku pracy, jest realizowanie przez nie zadań określonych w usta$w_{i e}^{2}$. Oczywiście pomimo tego, że wyliczenie przez ustawodawcę wskazanych wyżej podmiotów ma charakter wyczerpujący (numerus clausus), to jednak skuteczna reakcja na nowe problemy rynku pracy jest także możliwa poprzez prywatyzację zadań publicznych. Chodzi o proces polegający na przekazywaniu podmiotom prywatnym zadań publicznych. Zabieg ten ma na celu zmniejszenie kosztów wykonawstwa, zwiększenie efektywności działań i tworzenie alternatywnych sposobów zaspokajania potrzeb ludności. W literaturze zostało to nazwane współdomeną państwa, samorządu terytorialnego i podmiotów niepublicznych ${ }^{3}$.

1 Tekst jedn. Dz.U. z 2008 r., Nr 69, poz. 415 z późn. zm.

2 Z. Góral, Ustawa o promocji zatrudnienia i instytucjach rynku pracy. Praktyczny komentarz, Wolters Kluwer SA, Warszawa 2011, s. 90.

3 M. Stachl, Prawo administracyjne - pojęcia, instytucje, zasady w teorii i orzecznictwie, Wolters Kluwer SA, Warszawa 2002, s. 217-218, 351. 


\section{PUBLICZNE SŁUŻBY ZATRUDNIENIA}

Publiczne służby zatrudnienia tworzy, obok ministra właściwego do spraw pracy, marszałków województw i starostów, przede wszystkim wojewoda. Jest on, na mocy swojej pozycji ustrojowej, wynikającej z ustawy z dnia 23 stycznia 2009 roku o wojewodzie i administracji rządowej w województwie ${ }^{4}$, upoważniony do sprawowania nadzoru nad realizacją zadań z zakresu rynku pracy. Dla przykładu wojewoda nadzoruje pracę wojewódzkiego urzędu pracy, wydaje licencję pośrednikom pracy i doradcom zawodowym, a także wydaje zezwolenia na pracę cudzoziemców.

Publiczne służby zatrudnienia zajmują się koordynowaniem polityki państwa w zakresie podstawowych usług rynku pracy. Nie oznacza to jednak, że decentralizacja tych usług obniża ich istotną wartość. Przeciwnie - czyni je niezwykle ważkimi i potrzebnymi w określonej społeczności. Do działań realizowanych przez publiczne służby zatrudnienia należy pośrednictwo pracy, poradnictwo zawodowe, planowanie rozwoju zawodowego oraz pomoc w aktywnym poszukiwaniu pracy. Pamiętać należy, że zgodnie z wyrażoną w Konstytucji RP zasadą pomocniczości, faktyczna i najbardziej skuteczna polityka zatrudnienia prowadzona jest przez powiatowe urzędy pracy. Do ich zadań należy w szczególności:

- udzielanie pomocy bezrobotnym w znalezieniu pracy,

- przyznawanie środków z funduszu pracy na podejmowanie działalności gospodarczej,

- prowadzenie poradnictwa zawodowego,

- świadczenie usług EURES (wdrażanie prawa swobodnego przepływu osób w Unii Europejskiej),

- wydawanie indywidualnych decyzji administracyjnych w zakresie przyznawania prawa do świadczeń przysługujących bezrobotnym (zasiłki dla bezrobotnych, staże absolwenckie, dodatki aktywizacyjne, dodatki szkoleniowe).

Pośrednictwo pracy jest głównym i najważniejszym zadaniem publicznych służb zatrudnienia. Praktyka funkcjonowania tego instrumentu wskazuje na jego niską skuteczność. Spowodowane jest to szeroko rozwiniętą siecią portali internetowych, zajmujących się umieszczaniem ofert pracy, praktyk i staży dla bezrobotnych. Głównym powodem takiego stanu rzeczy jest też brak rozliczania pracowników publicznych służb zatrudnienia z efektów ich pracy. Ponadto oferty pracy, znajdujące się w bazie publicznych służb zatrudnienia, nierzadko są nieatrakcyjne, i z psychologicznego punktu widzenia, pod wieloma względami nie odpowiadają słusznym wymaganiom osób poszukujących pracy.

Poradnictwo zawodowe, w tym planowanie rozwoju zawodowego, to usługa polegająca na korzystaniu z pomocy odpowiednio wykwalifikowanego doradcy

4 Dz.U. Nr 131, poz. 206. 
zawodowego, który służy pomocą w planowaniu rozwoju zawodowego, uwzględniając aktualne tendencje rynku pracy, oraz wykształcenie, umiejętności i sytuację życiową poszukującego pracy. Doradztwo zawodowe jest młodą dziedziną funkcjonującą na rynku pracy, która wymaga odpowiedniego wykwalifikowania osób zajmujących się doradztwem. Bez właściwego przygotowania merytorycznego, prawnego i psychologicznego doradca zawodowy będzie działał nieskutecznie i niewymiernie. Poszukujący pracy niedoceniają tej formy aktywizacji zawodowej, przejawiając niechęć do rozeznania w sobie innej ścieżki kariery zawodowej.

Pomoc w aktywnym poszukiwaniu pracy przejawia się również w możliwości korzystania z wielorakich szkoleń specjalistycznych, służących podnoszeniu kwalifikacji zawodowych.

Szkolenia te winny jak najczęściej znajdować się w ofercie publicznych służb zatrudnienia. W warunkach zmieniającej się gospodarki rynkowej kwestia dostosowania się do wymagań stawianych przyszłym pracownikom przez pracodawców może być realizowana poprzez uczestnictwo w pracach interwencyjnych, robotach publicznych, klubach pracy, a także umowach i stażach absolwenckich.

\section{OCHOTNICZE HUFCE PRACY}

Ochotnicze Hufce Pracy to państwowe jednostki wyspecjalizowane w działaniach na rzecz młodzieży, w szczególności młodzieży zagrożonej wykluczeniem społecznym oraz bezrobotnych do 25 roku życia.

OHP prowadzi swoją działalność w duchu efektywnego przeciwdziałania marginalizacji i wykluczeniu społecznemu młodzieży, a także w zakresie jej kształcenia i wychowania. Organy OHP, w drodze porozumień z pracodawcami, pozwalają swoim podopiecznym na zdobycie kwalifikacji zawodowych oraz uzupełnienie wymaganego prawem wykształcenia.

Działalność OHP jest niezwykle ważna z punktu widzenia wychowania młodego pokolenia, które zagrożone jest społecznym wykluczeniem z powodu objawiających się niemałych problemów z nauką. Poprzez swoją działalność OHP bardzo aktywnie włącza się w kształcenie i przygotowanie zawodowe tzw. trudnej młodzieży.

\section{AGENCJE ZATRUDNIENIA}

Agencje zatrudnienia to podmioty wpisane do rejestru podmiotów prowadzących agencje zatrudnienia. Agencje zatrudnienia są podmiotami o charakterze niepublicznym. Prowadzenie agencji zatrudnienia opiera się o swobodę prowadzenia działalności gospodarczej. Organem prowadzącym rejestr agencji zatrudnienia jest marszałek 
województwa. Istnieje ogólnopolski rejestr agencji zatrudnienia ${ }^{5}$. Do ich podstawowych zadań należy przede wszystkim pośrednictwo pracy, prowadzenie doradztwa personalnego i poradnictwa zawodowego oraz oferowanie swoim klientom ofert pracy tymczasowej, która w oparciu o umowę o pracy tymczasowej świadczona jest przez wielu młodych ludzi. Jej nieatrakcyjność polega na obniżonym wynagrodzeniu, które stanowi dochód własny takiej agencji.

Praca tymczasowa stanowi jednak niedoceniany atut wśród wielu poszukujących pracy. Jest ona pewnego rodzaju inicjacją w zatrudnienie i pomaga w odnalezieniu właściwej drogi zawodowej tym, którzy mają z tym nie lada problem bądź są jeszcze osobami niezdecydowanymi. Pomimo niepublicznego charakteru ich działalności agencje zatrudnienia dokładają wszelkich starań w zakresie pośrednictwa pracy i dzięki swej ofercie stanowią największą konkurencję dla publicznych służb zatrudnienia.

\section{INSTYTUCJE SZKOLENIOWE}

Instytucje szkoleniowe to publiczne i niepubliczne podmioty, prowadzące działalność mającą na celu wpływanie na jakość zasobów pracy. Instytucje te muszą być wpisane do rejestru, jaki prowadzi właściwy wojewódzki urząd pracy.

Instytucje te prowadzą kształcenie ustawiczne z zakresu kompetencji zawodowych oraz rozwijania umiejętności dotyczących poruszania się po rynku pracy. Narzędziami pozaszkolnego kształcenia ustawicznego są z pewnością kursy, seminaria, konferencje i szkolenia. Nierzadko w ofercie instytucji szkoleniowych znajdują się praktyki, staże czy też studia podyplomowe. Najczęściej instytucjami szkoleniowymi są firmy komercyjne, które działają dla osiągnięcia zysku. Jednakże prawo polskie zna przykłady zakładów doskonalenia zawodowego, które działają jako jednostki oświatowe prowadzące szkoły, szkoły wyższe, szkoły dla dorosłych i placówki doskonalenia zawodowego.

\section{DIALOG SPOŁECZNY I PARTNERSTWO NA RYNKU PRACY}

Rynek pracy w swej istocie nie jest bytem autonomicznym i przy ogromnej dynamice zmian, jaką się charakteryzuje musi opierać się na dialogu i współpracy z parterami społecznymi. Partnerzy społeczni w swej istocie koncentrują się na rozwiązywaniu problemów lokalnej społeczności i swoją działalnością wnoszą pożądany potencjał w aktywizację zawodową osób poszukujących pracy. Dla przykładu instytucjami dialogu i partnerstwa mogą być przedsiębiorstwa, związki zawodowe,

5 www.kraz.praca.gov.pl [dostęp: 2.05.2015]. 
organizacje kościołów i związków wyznaniowych, a także niezliczony szereg organizacji pozarządowych.

Jako wymierny przykład instytucji partnerstwa na rynku pracy należy wskazać gminne centra informacji. Dysponują one informacjami o ofertach pracy, instytucjach szkoleniowych, ośrodkach wspierania przedsiębiorczości i dotowaniem zakładania działalności gospodarczej, a także podstawowymi informacjami z zakresu szeroko rozumianego prawa pracy i danymi teleadresowymi instytucji rynku pracy.

Kolejnym przykładem mogą być wspomniane już ośrodki wspierania przedsiębiorczości, realizujące niezliczone programy szkoleniowe w zakresie zakładania i prowadzenia działalności gospodarczej, a także świadczące pomoc w zakresie przedsiębiorczości.

Oczywiście niezliczona sieć ośrodków pomocy społecznej, która na poziomie gminnym zapewnia wsparcie w przezwyciężaniu trudnej sytuacji życiowej, w tym patologii związanej poszukiwaniem pracy. Na pracownikach ośrodków pomocy społecznej ciąży niezwykła odpowiedzialność polegająca na właściwym zdiagnozowaniu problemu bezrobocia wraz z opracowaniem indywidualnego planu pomocowego jego współdziałania.

Należy w tym miejscu również wspomnieć o istnieniu naczelnej Rady Zatrudnienia. Jest ona organem opiniodawczo-doradczym ministra właściwego do spraw pracy, który zajmuje się inicjowaniem na szczeblu krajowym odpowiednich programów służących niwelowaniu zjawiska bezrobocia oraz popieraniem już istniejących powiązań pracodawców w zakresie odpowiedniej aktywizacji zawodowej dla osób poszukujących pracy.

\section{PODSUMOWANIE}

Funkcjonowanie działalności podmiotów wdrażających poszczególne instrumenty rynku pracy staje aktualnie w opozycji do komercjalizacji usług społecznych w zakresie przeciwdziałania bezrobociu. Zadania państwa przejmowane są przez firmy prywatne, instytucje działające poza systemem administracji publicznej czy też wreszcie przez pseudoagencje zatrudnienia. Ich działalność nastawiona na ewidentny zysk, staje się konkurencyjna dla państwowych służb rynku pracy. Nie powinno dostrzegać się w tym niczego złego, gdyż ich działalność prowadzi do realizacji zadań państwa w zakresie polityki zatrudnienia. Te zadania to szereg niezliczonych uprawnień, których nie sposób zmieścić w ramach tak krótkiego opracowania. Niniejszy artykuł należy raczej potraktować jako asumpt w poszukiwaniu właściwej instytucji potrzebnej nam do podjęcia pracy. Droga wydaje się daleka, jednakże znajomość instytucjonalno-prawnych ram, które stanowią obwarowanie rynku pracy pozwoli na ich odszukanie, szersze zaznajomienie się z ich działalnością i skorzystanie z ich pomocy. Pobożnym życzeniem pozostaje, aby ta pomoc okazała się skuteczna i przede wszystkim wymierna. 


\section{BIBLIOGRAFIA}

Baron-Wiaterek M., Instytucjonalno-prawne aspekty rynku pracy i promocji zatrudnienia, IPiSS, Warszawa 2008.

Góral Z., Ustawa o promocji zatrudnienia i instytucjach rynku pracy. Praktyczny komentarz, Wolters Kluwer SA, Warszawa 2011.

Stachl M., Prawo administracyjne - pojęcia, instytucje, zasady w teorii i orzecznictwie, Wolters Kluwer SA, Warszawa 2002.

\section{Źródła internetowe}

www.kraz.praca.gov.pl

\section{Akty prawne}

Ustawa z dnia 26 czerwca 1974 r. - Kodeks pracy, Dz.U. z 1998 r., Nr 21, poz. 94 z poźn. zm. Ustawa z dnia 20 kwietnia 2004 r. o promocji zatrudnienia i instytucjach rynku pracy, Dz.U. z 2008 r., Nr 69, poz. 415, z późn. zm. 